Assessment of postmenopausal bleeding: a cohort case study

Azhar Mousa Al-Turiahi ${ }^{*}$, Fawz Alla El-Dine, Sarah Hamza Herez

\begin{abstract}
The objective of this study is to assessment the postmenopausal bleeding (PMB), and investigated their causes, correlation with variable socio-demographic status. A 140women complaining of PMB were enrolled in this study, each patient had a proper questionnaire filled in, with appropriate investigations that included; ultrasonography, Pap smear, colposcopy with cervical biopsy and endometrial curettage to take endometrial biopsy for histopathology. Nearly all cases were married 135 (96.4\%), most of them were obese and overweight 97(69.3\%), 43(30.7\%) were having normal body mass index. Various etiology of PMB were found in this study; endometrial cancer $(9.3 \%)$, cervical cancer $(0.7 \%)$, atrophic endometritis $(7.1 \%)$, atrophic vaginitis $(2.8 \%)$, endometrial hyperplasia (45\%), cervicitis-CIN (15.7\%), cervical polyp (12.8\%), and endometrial polyp (18.6\%). Bleeding from benign causes and of endometrial cancer occurs at fifth decade and sixth decade of life, while from cervical cancer occurs at seventh decade. The pattern of PMB; mild bleeding significantly higher in cervicitis-CIN; moderate bleeding more in endometrial polyp and significantly higher than mild and sever bleeding; while severe bleeding was significantly associated in endometrial cancer. Duration of PMB had a vast range (4 days to 5 years). $24.83 \%$ of cases had prolonged bleeding $>6$ months, $(48.7 \%)$ with endometrial hyperplasia, (12.8\%) had endometrial cancer. The endometrial cancer present in $10 \%$ of the patients with recurrent PMB.
\end{abstract}

Keywords: Postmenopausal bleeding; Endometrial cancer; Colposcopy

${ }^{*}$ Corresponding Author: Azhar Mousa Al-Turiahi
${ }^{1}$ Department of Gynecology and Obstetrics, College of Medicine, Kufa University
Received February 08, 2016; accepted June 29, 2016; published July 09, 2016
Copyright @ 2017 AA. This is article distributed under the terms of the Creative Commons Attribution
License (http://creativecommons.org), which permits unrestricted use, distribution, and reproduction in
any medium, provided the original work is properly cited. (cc) $\mathrm{EY}$

\title{
Introduction
}

The term menopause is derived from the Greek Menos (month) and Pausis (cessation) is defined as the last menstrual period [1]. The diagnosis can only be made retrospectively after a minimum of 1 year's amenorrhea, or 6months according to some [2]. In most women, menopause occurs between the ages of 50 and 55 years, with an average age of 51.5years. PMB is defined as bleeding that occurs after 12 months of amenorrhea in middle-aged women [3]. An arbitrary time limit of one year's amenorrhea is generally set but some prefer to reduce 
the period to 6 months [4]. Neither normal (functional) bleeding nor dysfunctional bleeding should occur after the menopause. Atrophic or proliferative endometrium is not unusual. Secretary patterns should not occur unless the patient has resumed ovulation or has received progesterone therapy. PMB is more likely to be caused by pathologic disease than is bleeding in younger women and must always be investigated [3]. Approximately $10 \%$ of these PMB have a gynecological malignancy. Women should be regarded as having malignancy until proved otherwise. Around $10 \%$ of women with PMB will have primary or secondary malignancy; endometrial cancer (80\%), cervical cancer or rarely an ovarian tumor [5]. PMB accounts for a significant proportion of gynecological referrals and occurs in approximately $3 \%$ of postmenopausal women [6]. The incidence of PMB is strongly correlated with the time since menopause. The estimated incidence was 409/1000 person-years immediately after the first 12 months of amenorrhea following the menopause, falling to 42/1000 person-years more than 3 years after the menopause [7]. The risk of endometrial carcinoma in women with $\mathrm{PMB}$ rises with age from approximately $1 \%$ at the age of 50 years to approximately $25 \%$ at the age 80 years [8]. In patients who have had only one episode of slight PMB, it is common (12$50 \%$ ) not to find any abnormality. Of patients with negative findings who have bled only once before curettage, 70-80\% do not bleed again afterwards.
Evaluation of uterine bleeding in postmenopausal women

1. History: Detailed history should be obtained to identify the most likely etiology of the bleeding $[9,10]$, key questions when a woman presents with postmenopausal bleeding include:

- what the results of the last cervical smear?Is there any history of cervical abnormality?

- When was the last natural menstrual period?

- When did the postmenopausal bleeding start?

- How heavy is the bleeding, and how long does it last?

- Where there are precipitating factors such as trauma, including intercourse?

- Are there any associated symptoms such as pain, fever or changes in bladder or bowel function?

- Deos she use, or has she used, hormone replacement therapy? what type and for how long?

- Are there any risk factors for endometrial cancer?

- Age: peak incidence is between $65-75$ years.

- Nulliparity

- Early menarche <12 years and late menopause $>50$ years

- Regularity of the menstrual cycle (PCOS)

- Personal history of diabetes mellitus or hypertension.

-Past medical history of endometrial hyperplasia or polyps.

-Past medical history of breast or ovarian tumors. 
-Drug history of exogenous estrogen excess.

- Unopposed estrogen replacement therapy.

- Tamoxifen

- Family history of hereditary non polyposis colon cancer(HNPCC).

2. Physical Examination: A careful physical examination of the external and internal anatomy of the female genital tract is crucial. A diagnosis cannot be established and a treatment plan must not be instituted without a pelvic examination. Speculum examination should be performed to see if a source of bleeding can be identified (bladder, rectum, vulva, vagina and uterus), to assess atrophic changes in the vagina and to note any suspicious lesions, lacerations or foreign bodies. A bimanual pelvic examination is necessary to look for the size, position, mobility, contour and tenderness of the uterus. In addition, a general examination should be performed to look for signs of systemic illness [11, $12,14]$.

3. Basic Laboratory Evaluation: All women who experience PMB must be evaluated for endometrial cancer since age is a significant risk factor for this disorder, mainly by Transvaginal Sonography (TVS) [17, 18], Saline infusion sonohysterography (SIS) [19], Dilatation and curettage (D\&C) [20], Endometrial biopsy and aspiration [21], Hysteroscopy, Cervical Cytology [22].

The aim of the study is to find out common causes of $\mathrm{PMB}$, determine correlation between socio-demographic factors with the causes of PMB, and detect the relation and risk factors related to cervical and endometrial cancer.

\section{Patient and method}

\section{Study design}

Across sectional study was conducted over a period of 12 months from the $1^{\text {st }}$ january 2015 to the $31^{\text {st }}$ December 2015 in all public hospitals in Al-Najaf governorate : Al-Zahraa maternity teaching hospital, Al-Sader teaching hospital, Al-Hakim general hospital, AlForat general hospital, Al-Manathera general hospital, Al-Sajad general hospital, Al-Haidaria general hospital, with two private hospitals (Al-Ameer private hospital, Al-Ghadeer private hospital). 140 postmenopausal women presented with bleeding were collected. A detailed close ended questionnaire was used to collect the data after verbal consent was obtained. By interviewing these women information were collected about different demographic factors like age, socio-economic status,...etc. The collected data were put in master chart. They were grouped and tabulated according to the various criteria and results were analyzed. Following thorough examination, each patient had ultrasound scan at department of radiology, the following criteria were assessed: Endometrial thickness, uterine size, presence of any fibroid, polyp of any size, fluid inside uterine cavity or any mass in the pelvic cavity. Fractional curettage was arranged on specialist's operation list (committee \& family acceptance recorded for unmarried patients). Preoperative preparation was including blood count, hemoglobin, renal function test, ECG, chest X-ray, blood sugar, then curettage was performed under GA (6 samples taken from endocervix, anterior, posterior, two lateral 
and fundal wall of the uterus were taken, and the sample sent for histopathological examination to a senior pathologist. According to the result of these investigations the etiology of bleeding was identified, the treatment decided by gynecologist according to the etiology.

Later on the tissues obtained by hysterectomy were examined by a senior pathologist to confirm the diagnosis(only three cases were unfit for hysterectomy). At the end of the study the etiology of bleeding obtained and classified as following; the endometrial causes include, endometrial atrophy, endometrial polyp, hyperplasia or carcinoma, and cervical lesion were classified as inflammatory, polyp, dysplasia and carcinoma.

\section{Statistical analysis}

Microsoft excel computer program version eight. The software used for data analysis is SPSS (statistical package for social sciences) Version 20, means, frequencies and percentages were calculated. A $\mathrm{p}$ value of $\leq 0.05$ was considered as statistically significant.

\section{Results}

140 postmenopausal women presented with pervaginal bleeding were included in this study their ages ranged from 46-80years old, with mean age of $58.6 \pm 7.2$ years.

- Of these 140 cases ,115 cases on histopathological examination found to have genital tract pathology, $90 \%$ had benign pathology while $10 \%$ had malignancy

- 15 cases had normal endometrial tissue.
- 10 cases had inadequate endometrial tissue sample for histopathological examination.

- 38 cases had multiple pathological causes for PMB.

Socio- demographic variables

- Age: it is clear that most bleeding episodes were between 50-59 yrs \& incidence of bleeding is decreased with age.

- Marital state: only five cases were unmarried others were married (135 cases)

- Social class: most of the cases were from low and middle social classes (overcrowding and poverty) only 5 cases from high social class (high standard of living).

- Smoking: 29 patients were smokers others weren't

- Parity: from above data appears that most of the patients were multipara \& grandmultipara only five were nullipara.

- Medical comorbidity: $62.2 \%$ of them were affected by chronic medical disease (HTN or DM). 
○ 13 patients had ischemic heart diseases.

- 1 patient had thyroidectomy and on thyroxin treatment.
○ 1 patient had psychiatric problem.

- 1 patient had chronic liver disease.

- BMI: Obesity was a clear factor.

Table 1.

Socio-demographic variables

\begin{tabular}{|c|c|c|c|}
\hline Variable & & Frequency & Percentage $\%$ \\
\hline \multirow{4}{*}{ Age/years } & $40-49$ & 7 & 5.0 \\
\hline & $50-59$ & 68 & 48.6 \\
\hline & $60-69$ & 50 & 35.7 \\
\hline & $\geq 70$ & 15 & 10.7 \\
\hline \multirow{2}{*}{ Marital status } & Married & 135 & 96.4 \\
\hline & Unmarried & 5 & 3.6 \\
\hline \multirow{3}{*}{$\begin{array}{c}\text { Socioeconomic } \\
\text { status }\end{array}$} & Low & 51 & 36.4 \\
\hline & Moderate & 84 & 60 \\
\hline & High & 5 & 3.6 \\
\hline \multirow{2}{*}{ Occupation } & Employed & 8 & 5.7 \\
\hline & Unemployed & 132 & 94.3 \\
\hline \multirow{2}{*}{ Smoking } & Yes & 29 & 20.7 \\
\hline & No & 111 & 79.3 \\
\hline \multirow{3}{*}{ Parity } & Nullipara & 5 & 3.6 \\
\hline & $1-4$ & 67 & 47.8 \\
\hline & $\geq 5$ & 68 & 48.6 \\
\hline \multirow{4}{*}{$\begin{array}{l}\text { Medical } \\
\text { comorbidity }\end{array}$} & Hypertension & 46 & 32.9 \\
\hline & $\mathrm{DM}$ & 13 & 9.3 \\
\hline & Both & 28 & 20 \\
\hline & Nill & 53 & 37.8 \\
\hline \multirow{4}{*}{ BMI } & $18-24.9$ & 43 & 30.7 \\
\hline & $25-29.9$ & 65 & 46.5 \\
\hline & $30-40$ & 31 & 22.1 \\
\hline & $>40$ & 1 & 0.7 \\
\hline
\end{tabular}

Frequency percentage of different etiologies

Table (2) shows that endometrial hyperplasia is a major cause of postmenopausal bleeding (45\%), while endometrial polyp comes next $(18.6 \%)$ followed by cervisitis CIN (15.7\%) and endocervical polyp (12.8\%).
While the frequency percentage of liomyomas (12.1\%), endometrial cancer was (9.3\%), atrophic endometritis and atrophic vaginitis $(9.9 \%)$, the reminder include adenomyosis (2.8\%) ,endometrial polyp (5.5\%) and cervical cancer was $(0.7 \%)$ Table (2). 
Table 2.

Frequency percentages of different etiologies

\begin{tabular}{|c|c|c|}
\hline Histopathological findings & No. of cases & Percentage $\%$ \\
\hline Endometrial hyperplasia & 63 & $45 \%$ \\
\hline Endometrial polype & 26 & $18.6 \%$ \\
\hline Cervicitis-CIN & 22 & $15.7 \%$ \\
\hline Endocervical polype & 18 & $12.8 \%$ \\
\hline Lieomyoma & 17 & $12.1 \%$ \\
\hline Endometrial cancer & 13 & $9.3 \%$ \\
\hline Atrophic endometrium & 10 & $7.1 \%$ \\
\hline Atrophic vaginitis & 4 & $2.8 \%$ \\
\hline Cervical cancer & 1 & $0.7 \%$ \\
\hline
\end{tabular}

Variables- endometrial hyperplasia and malignancies

Table (3) shows relation between factors that considered as a risk factor for (Endometrial cancer- cervical cancer and endometrial hyperplasia). Age: as it's clear from table (1) that most common age for endometrial hyperplasia is $5^{\text {th }}$ decade, 35out of 63 cases were between 50-59 yrs of age and it is the sixth decade for endometrial cancer, 7 out of 13 cases were between 60-69 years of age. While for $\mathrm{Ca}$ cervix the dominant age was $7^{\text {th }}$ decade (only one case detected). Parity: in relation to endometrial cancer all cases were married only one case nulliparous and 12 cases halved between multiparus and grandmultiparous.

While with hyperplasia 3 cases were unmarried, 37 cases multipara \& for cervical cancer case was grandmultipara. Exogenous estrogen and HRT: none of the cases with endometrial and cervical cancer were receiving HRT. Smoking: in relation to endometrial cancer 3 out of 10 cases were smokers while from 63 cases of endometrial hyperplasia 21 of them were smokers, and the case of cervical $\mathrm{Ca}$ was nonsmoker. Medical disease: 1 case of endometrial Carcinoma had HTN, 2 cases have DM and 5 of them had both DM and HTN, those with hyperplasia 26 of them had HTN, 9 DM and 7 of them had both, while the case of cervical cancer had both. BMI: most of cases with endometrial cancer were obese or overweight; those with cervical cancer were within normal range for BMI. Family history of relevant cancer: from those who had endometrial cancer only 2 of them had family history of endometrial cancer and one case had family history of breast cancer. 
Table 3.

Variables-Endometerial hyperplasia\&malignancies

\begin{tabular}{|c|c|c|c|c|}
\hline Variable & & $\begin{array}{l}\text { Endometrial } \\
\text { hyperplasia }\end{array}$ & $\begin{array}{c}\text { Endometrial } \\
\text { cancer }\end{array}$ & $\begin{array}{c}\text { Cervical } \\
\text { cancer }\end{array}$ \\
\hline \multirow[t]{4}{*}{ Age/years } & $40-49(n=7)$ & $2(13.3 \%)$ & $0(0 \%)$ & $0(0 \%)$ \\
\hline & $50-59(n=68)$ & $35(51.5 \%)$ & $3(4.4 \%)$ & $0(0 \%)$ \\
\hline & $60-69(n=50)$ & $19(38 \%)$ & $7(14 \%)$ & $0(0 \%)$ \\
\hline & $\geq 70(n=15)$ & $7(46.7 \%)$ & $3(20 \%)$ & $1(6.7 \%)$ \\
\hline \multicolumn{2}{|c|}{$P$ value } & 0.404 & 0.111 & 0.133 \\
\hline \multirow[t]{4}{*}{ Parity } & Unmarried(n=5) & $3(60 \%)$ & $0(0 \%)$ & $0(0 \%)$ \\
\hline & Nullipara(n=5) & $2(40 \%)$ & $1(20 \%)$ & $0(0 \%)$ \\
\hline & $1-4(n=67)$ & $37(55.2 \%)$ & $6(8.9 \%)$ & $0(0 \%)$ \\
\hline & $\geq 5(n=68)$ & $21(30.8 \%)$ & $6(8.8 \%)$ & $1(1.4 \%)$ \\
\hline \multicolumn{2}{|c|}{ P value } & 0.061 & 0.933 & 0.133 \\
\hline $\begin{array}{c}\text { Exogenous } \\
\text { hormones }\end{array}$ & & $0(0 \%)$ & $0(0 \%)$ & $0(0 \%)$ \\
\hline \multirow[t]{2}{*}{ Smoking } & $\operatorname{Yes}(n=29)$ & $21(72.4 \%)$ & $3(10.3 \%)$ & $0(0 \%)$ \\
\hline & $\mathrm{No}(\mathrm{n}=111)$ & $42(37.8 \%)$ & $10(9 \%)$ & 1 \\
\hline \multicolumn{2}{|c|}{$P$ value } & $<0.001$ & 0.824 & 0.468 \\
\hline \multirow{4}{*}{$\begin{array}{c}\text { Medical } \\
\text { comorbidity }\end{array}$} & Hypertension $(n=46)$ & $26(56.5 \%)$ & $1(2.2 \%)$ & $0(0 \%)$ \\
\hline & $\operatorname{DM}(n=13)$ & $9(69.2 \%)$ & $2(15.4 \%)$ & $0(0 \%)$ \\
\hline & $\operatorname{Both}(n=28)$ & $7(25 \%)$ & $5(17.8 \%)$ & $1(3.5 \%)$ \\
\hline & $\operatorname{Nill}(n=53)$ & $21(39.6 \%)$ & $5(9.4 \%)$ & $0(0 \%)$ \\
\hline \multicolumn{2}{|c|}{$P$ value } & 0.013 & 0.307 & 0.497 \\
\hline \multirow[t]{4}{*}{ BMI } & $18-24.9(n=43)$ & $19(44.2 \%)$ & $2(4.6 \%)$ & $0(0 \%)$ \\
\hline & $25-29.9(\mathrm{n}=65)$ & $17(26.1 \%)$ & $4(6.2 \%)$ & $1(1.5 \%)$ \\
\hline & $30-40(n=31)$ & $26(83.8 \%)$ & $7(22.6 \%)$ & $0(0 \%)$ \\
\hline & $>40(n=1)$ & $1(100 \%)$ & $0(0 \%)$ & $0(0 \%)$ \\
\hline \multicolumn{2}{|c|}{$P$ value } & $<0.001$ & 0.045 & 0.762 \\
\hline
\end{tabular}

This table shows significant association between multiparty, smoking and medical co morbidity especially diabetes mellitus with endometrial hyperplasia, also there is significant association between body mass index with endometrial hyperplasia and endometrial cancer where higher percentage of cases were among obese women. Majority of patients presenting with postmenopausal bleeding were observed in the first phase (1-5yrs) of clear span: (71) cases which represent (45.2\%) followed by second phase (37) cases which represent (23.5) \%. In the first phase of clear span the predominant pathology was endometrial hyperplasia (45\%). In second phase of clear span the predominant pathology was endometrial polyp endometrial hyperplasia. In third phase (19.1\%) predominant pathology was cervicitis, endometrial hyperplasia and cancer of 
cervix. In phase four of clear span (12.1\%) the predominant pathology was endometrial hyperplasia \&endometrial carcinoma.

Table 4.

Different etiology-clear span

\begin{tabular}{|c|c|c|c|c|}
\hline \multirow{2}{*}{ Diagnosis } & \multicolumn{4}{|c|}{ Clear span } \\
\cline { 2 - 5 } & $\begin{array}{c}1-5 \mathrm{Y} \\
(45.2 \%)\end{array}$ & $\begin{array}{c}6-10 \mathrm{Y} \\
(23.5 \%)\end{array}$ & $\begin{array}{c}11-15 \mathrm{Y} \\
(19.1 \%)\end{array}$ & $\begin{array}{c}>15 \mathrm{Y} \\
(12.1 \%)\end{array}$ \\
\hline Cervicitis-CIN & 9 & 4 & 8 & 1 \\
\hline $\begin{array}{c}\text { Endometrial } \\
\text { polype }\end{array}$ & 7 & 12 & 5 & 2 \\
\hline $\begin{array}{c}\text { Endocervical } \\
\text { polype }\end{array}$ & 8 & 6 & 3 & 1 \\
\hline Atrophic vaginitis & 3 & 0 & 1 & 0 \\
\hline $\begin{array}{c}\text { Atrophic } \\
\text { endometritis }\end{array}$ & 3 & 2 & 2 & 3 \\
\hline $\begin{array}{c}\text { Endometrial } \\
\text { hyperplasia }\end{array}$ & 37 & 11 & 8 & 7 \\
\hline $\begin{array}{c}\text { Endometrial } \\
\text { cancer }\end{array}$ & 3 & 2 & 3 & 5 \\
\hline Cervical CA & 1 & 0 & 0 & 0 \\
\hline
\end{tabular}

In this table there is no significant association between clear span and different etiologies except endometrial hyperplasia which is significantly higher in the period 1-5 years. Table (5), shows that most of the cases had moderate (one soaked pad daily) PMB (45\%), mild (spotting) PMB represented $(40.7 \%)$ and sever (two or more soaked pads) PMB represented (14.3\%). (50.79\%) of patients with endometrial hyperplasia had moderate PMB, while $(30.15 \%)$ of cases had mild PMB and (19\%) revealed sever PMB. Most patients with endometrial polyp complained from moderate bleeding $(69.2 \%)$, mild and sever bleeding represent (23.1\%) and (7.7\%) respectively. (53.84\%) of patients with endometrial carcinoma had moderate PMB, $(30.76 \%)$ of cases had mild PMB and $(15.38 \%)$ of them had sever PMB. The case of cervical carcinoma had moderate PMB. Most cases of cervicitis (77.3\%) had mild uterine bleeding and the remainder cases (22.3\%) had moderate bleeding. (61.1\%) of cases with endocervical polyp had mild PMB and $(38.9 \%)$ of them had moderate bleeding. All cases of Atrophic vaginitis complained from mild PMB, while $(50 \%)$ of atrophic endometeritis revealed mild bleeding, (40\%) had moderate bleeding and $(10 \%)$ had sever PMB. 
Table 5.

Different etiology- Amount of PMB

\begin{tabular}{|c|c|c|c|c|}
\hline \multirow[b]{2}{*}{ Diagnosis } & \multicolumn{3}{|c|}{ Amount of PMB } & \multirow[t]{2}{*}{$P$ value } \\
\hline & $\begin{array}{l}\text { Mild } \\
n=64\end{array}$ & $\begin{array}{c}\text { Moderate } \\
n=71\end{array}$ & $\begin{array}{l}\text { Sever } \\
n=22\end{array}$ & \\
\hline Cervicitis-CIN & $\begin{array}{c}17 \\
(77.3 \%)\end{array}$ & $\begin{array}{c}5 \\
(22.7 \%)\end{array}$ & $0(0 \%)$ & $<0.001$ \\
\hline Endometrial polype & $\begin{array}{c}6 \\
(23.1 \%)\end{array}$ & $\begin{array}{c}18 \\
(69.2 \%)\end{array}$ & $\begin{array}{c}2 \\
(7.7 \%)\end{array}$ & 0.026 \\
\hline Endocervical polype & $\begin{array}{c}11 \\
(61.1 \%)\end{array}$ & $\begin{array}{c}7 \\
(38.9 \%)\end{array}$ & $0(0 \%)$ & 0.078 \\
\hline Atrophic vaginitis & $\begin{array}{c}4 \\
(100 \%)\end{array}$ & $\begin{array}{c}0 \\
(0 \%)\end{array}$ & $0(0 \%)$ & 0.204 \\
\hline Atrophic endometritis & $\begin{array}{c}5 \\
(50 \%)\end{array}$ & $\begin{array}{c}4 \\
(40 \%)\end{array}$ & $\begin{array}{c}1 \\
(10 \%)\end{array}$ & 0.972 \\
\hline Endometrial hyperplasia & $\begin{array}{c}19 \\
(30.2 \%)\end{array}$ & $\begin{array}{c}32 \\
(50.8 \%)\end{array}$ & $\begin{array}{c}12 \\
(19 \%)\end{array}$ & 0.063 \\
\hline Endometrial cancer & $\begin{array}{c}2 \\
(15.4 \%)\end{array}$ & $\begin{array}{c}4 \\
(30.7 \%)\end{array}$ & $\begin{array}{c}7 \\
(53.9 \%)\end{array}$ & $<0.001$ \\
\hline Cervical CA & $\begin{array}{c}0 \\
(0 \%)\end{array}$ & $\begin{array}{c}1 \\
(100 \%)\end{array}$ & $\begin{array}{c}0 \\
(0 \%)\end{array}$ & 0.620 \\
\hline
\end{tabular}

In table 5 shows that mild bleeding significantly higher in cervicitis-CIN, In endometrial polyp the moderate bleeding is significantly higher than mild and sever bleeding ,while endometrial cancer was significantly associated with amount of bleeding were most cases had severe bleeding. Table (6), shows that the duration of PMB was between (1week-1month) in $(33.1 \%)$ of cases and it was between (1month-6months) and in (31.2\%), $(15.9 \%)$ of cases had PMB of (>6months-12months) duration, the reminder cases were $(10.8 \%)$ presented within (a week) duration and only
(8.9\%) had PMB of (more than 1year duration). Duration of PMB had a vast range (4 days to 5 years). (24.83\%) of cases had prolonged bleeding $>6$ months, of these (48.7\%) had endometrial hyperplasia and (12.8\%) had endometrial cancer. In this study the incidence of recurrent PMB was $25.47 \%$, of these $40 \%$ had endometrial hyperplasia, while $10 \%$ of the patients with recurrent $\mathrm{PMB}$ had endometrial cancer. The incidence of recurrent bleeding was $(25.47 \%)$; most of these patients had a previous dilatation and curettage. 
Table 6.

Different etiology- Duration of PMB

\begin{tabular}{|c|c|c|c|c|c|c|}
\hline \multirow[b]{2}{*}{ Diagnosis } & \multicolumn{5}{|c|}{ Duration of PMB } & \multirow[t]{2}{*}{$P$ value } \\
\hline & $\begin{array}{l}<1 w k \\
n=17\end{array}$ & $\begin{array}{c}1 w k-1 m \\
n=52\end{array}$ & $\begin{array}{c}>1-6 m \\
n=49\end{array}$ & $\begin{array}{c}>6-12 m \\
n=25\end{array}$ & $\begin{array}{c}>1 y \\
n=14\end{array}$ & \\
\hline Cervicitis-CIN & $\begin{array}{c}2 \\
(9 \%)\end{array}$ & $\begin{array}{c}9 \\
(40.9 \%)\end{array}$ & $7(31.8 \%)$ & $\begin{array}{c}3 \\
(13.6 \%)\end{array}$ & $\begin{array}{c}1 \\
(4.5 \%)\end{array}$ & 0.979 \\
\hline Endometrial polype & $0(0 \%)$ & $\begin{array}{c}8 \\
(30.7 \%)\end{array}$ & $\begin{array}{c}9 \\
(34.6 \%)\end{array}$ & $\begin{array}{c}8 \\
(30.7 \%)\end{array}$ & $\begin{array}{c}1 \\
(3.8 \%)\end{array}$ & 0.207 \\
\hline Endocervical polype & $\begin{array}{c}2 \\
(11.1 \%)\end{array}$ & $9(50 \%)$ & $\begin{array}{c}5 \\
(27.9 \%)\end{array}$ & $\begin{array}{c}1 \\
(5.5 \%)\end{array}$ & $\begin{array}{c}1 \\
(5.5 \%)\end{array}$ & 0.764 \\
\hline Atrophic vaginitis & $\begin{array}{c}1 \\
(25 \%)\end{array}$ & $\begin{array}{c}2 \\
(50 \%)\end{array}$ & $\begin{array}{c}1 \\
(25 \%)\end{array}$ & $\begin{array}{c}0 \\
(0 \%)\end{array}$ & $\begin{array}{c}0 \\
(0 \%)\end{array}$ & 0.996 \\
\hline $\begin{array}{c}\text { Atrophic } \\
\text { endometritis }\end{array}$ & $1(10 \%)$ & $6(60 \%)$ & $\begin{array}{c}3 \\
(30 \%)\end{array}$ & $\begin{array}{c}0 \\
(0 \%)\end{array}$ & $\begin{array}{c}0 \\
(0 \%)\end{array}$ & 0.613 \\
\hline $\begin{array}{l}\text { Endometrial } \\
\text { hyperplasia }\end{array}$ & $\begin{array}{c}9 \\
(14.3 \%)\end{array}$ & $\begin{array}{c}16 \\
(25.4 \%)\end{array}$ & $\begin{array}{c}19 \\
(30.1 \%)\end{array}$ & $\begin{array}{c}11 \\
(17.5 \%)\end{array}$ & $\begin{array}{c}8 \\
(12.7 \%)\end{array}$ & 0.175 \\
\hline Endometrial cancer & $\begin{array}{c}2 \\
(15.3 \%)\end{array}$ & $\begin{array}{c}2 \\
(15.3 \%)\end{array}$ & $\begin{array}{c}4 \\
(30.6 \%)\end{array}$ & $\begin{array}{c}2 \\
(15.3 \%)\end{array}$ & $\begin{array}{c}3 \\
(23.07 \%)\end{array}$ & 0.477 \\
\hline Cervical CA & $\begin{array}{c}0 \\
(0 \%)\end{array}$ & $\begin{array}{c}0 \\
(0 \%)\end{array}$ & $\begin{array}{c}1 \\
(100 \%)\end{array}$ & $\begin{array}{c}0 \\
(0 \%)\end{array}$ & $\begin{array}{c}0 \\
(0 \%)\end{array}$ & 0.345 \\
\hline
\end{tabular}

\section{Discussion}

PMB is considered as an important and alarming symptom both to the patient and the gynecologist [23]. The incidence of PMB declines with succeeding years after menopause and that the incidence of endometrial carcinoma increases as the age of the patient with PMB increases [24] and as observed by other [25]. The result of this study is comparable to this observation, the frequency of bleeding after seventy years are decrease; only ten cases were reported. The most common age for occurrence of bleeding in post menopause in this study is fifth decade and is comparable to the result of other study [26]. Endometrial cancer is one of the most common gynecological malignancies, the peak incidence for endometrial cancer is between (65- 75years) of age (12) which is higher than the result of this study (the peak incidence for endometrial cancer is between (60-69 years) of age), also this result is lower than the peak incidence for endometrial cancer [27] (which is between 65-74years) but, it is higher than other study which showed peak incidence between50-54years. Excessive estrogen is associated with most of the risk factors that have been linked to endometrial carcinoma [28]. Either endogenous or from exogenous source, this is in regard to early menarche and late menopause [29]. All 13 cases with endometrial cancer had menarche below 14 years of age and 9 out of 13 had menopause after 50 years. Nulliparity and infertility associated with 
anovulation is considered a risk factor for endometrial cancer, pregnancy reduces the risk of endometrial cancer by $30 \%$ after the first birth and by $25 \%$ with each subsequent birth [30], in this study all cases of endometrial carcinoma were married, among those one of them was infertile, the parity range from 4-9, so there is no evidence for the risk to decline with increasing number of birth [31].

Exogenous estrogen: in this study all cases were non user of HRT, because usage of HRT isn't common in our community. Obesity is another risk factor studied. Increased body mass index is one of the major risk factors for the PMB and hence malignancy [32]. Seven cases with endometrial cancer were obese \&4 cases were overweight. 30 out of 63 cases with hyperplasia were obese $\& 17$ were overweight. Another risk factor for endometrial cancer is a family history of endometrial cancer.

The greatest risk appears to be in first degree relatives, genetic disease represent up to $10 \%$ of cases [33], 3 cases with endometrial cancer have a family history of related cancers, 2 with breast cancer \& one case with endometrial cancer. Medical disease including DM and HTN are common medical problems in patients with post menopausal bleeding these are significantly associated with endometrial cancer, but a causal relationship not been confirmed yet [34].

It is important to mention that all risk factors are based on probabilities, and even someone without any risk factors can still get endometrial cancer. Cervical carcinoma is vastly more common in developing countries; there are several known risk factors for getting cervical cancer. One of the most important risk factors for cervical cancer is infection with a virus called HPV. HPV which is the virus that causes genital warts, but having genital warts doesn't necessarily mean you are going to get cervical cancer. However, almost all cervical cancers have evidence of HPV virus in them. In this study this has not been assessed because of unavailability of HPV studying.

Any risk factors for developing sexually transmitted diseases are also risk factors for developing cervical cancer. Another important risk factor for developing cervical cancer is smoking. In this study only one case had cervical cancer, she was smoker, and we don't have adequate power to definitively test actual risk of smoking on cervical cancer. In this study the clear span divided in 4 phases, it was observed that hyperplasia predominantly observed in phase one as result by other [35].

The incidence of malignancy increases with delay in presentation, while incidence of atrophic changes \& cervicitis appears mostly in phase $1 \& 3$. In general with advancing in age, the incidence of bleeding decreases which represents phase $3 \& 4$ of clear span, in phase 4 only $(12.1 \%)$ of cases were present while phase one represents( $45.2 \%$ ) of cases. As shown in this study endometrial hyperplasia with or without atypia was the predominant finding in about $(45 \%)$ of cases which is higher than the result of many other studies [36]. Frequency percentage of cervical and endometrial polyp together was about $(31.4 \%)$ in this study which is higher than that reported by others [37]. 
Frequency percentage of atrophic endometritis-vaginitis was $(9.9 \%)$ of cases. The exact cause of bleeding from atrophic endometritis isn't known, it may be due to anatomic vascular variation or local haemostatic mechanism [38].

The absolute risk of endometerial cancer in non-user of HRT who present with PMB ranges from (5.7-11.5\%) [7], the frequency percentage of endometrial carcinoma is $(9.28 \%)$ in this In this study the frequency percentage of Cervical cancer is $(0.7 \%)$. Exogenous estrogen: the percentage is zero, this is most likely due to small number of women in our society that use HRT in postmenopausal years due to lack of awareness about its advantages.

The frequency percentage of cervicitisCIN was (15.7\%), which was the $3 \mathrm{rd}$ etiology of postmenopausal bleeding in this study, which is higher than other study [39]. There is no evidence to indicate whether different patterns of PMB such as one-off bleeding or more frequent bleeds are more likely to be associated with malignancy [40]. Women with recurrent PMB after initial negative investigations are no more likely to have endometrial cancer than those presenting for the first time but re-investigation is indicated if six months has elapsed [41]. Longer lasting bleeding episodes, higher amount of bleeding and recurrent bleeding episodes were the clinical characteristics associated with endometrial cancer [42].

In this study $(53.9 \%)$ of patients with endometrial cancer had sever uterine bleeding, while $(19 \%)$ of patients with endometrial hyperplasia had sever PMB and $(38.43 \%)$ of patients with endometrial cancer had prolonged
PMB $>6$ month. The incidence of recurrent PMB was $(25.47 \%)$, of these, $(10 \%)$ had endometrial cancer, $(40 \%)$ of the patients with recurrent PMB had endometrial hyperplasia in this study.

\section{Conclusions}

Majority of cases with post menopausal bleeding were having benign causes $90 \%$, however malignancies were very important etiology of bleeding in this age group, it constitute 10\%. Malignant cases were either endometrial cancer (9.3\%) or cervical cancer (0.7\%), obesity was significant morbidity in this age group.

Suspicion of endometrial carcinoma increases if PMB is associated with other factors like medical illness (HTN, DM).

Investigations like ultrasonography, Pap smear and endometrial biopsy are essential to diagnose causes of PMB. For women who present with postmenopausal bleeding and a benign tissue diagnosis, recurrent bleeding is a worrisome problem and reinvestigations should be carried out as hysterscopy.

\section{References}

1. Panay N. Menopause \& the postmenopausal women. Dewhurst's text book of Obstetrics \& Gynecology for post graduate. Blackwell, 7th edition 2007;47:479-495.

2. Kaur M, Singh R, Sharma $M$. Endovaginal sonographic evaluation of postmenopausal uterine bleeding. Journal of Clinical and Diagnostic Research 2010;4:2175- 82.

3. Decherny A, Nathen L, Goodwin T, Lawfer N. Complications of 
menstruation; abnormal uterine bleeding. Current Obstetrics \&Gynecology diagnosis \& treatment, Lang 10th edition 2007;35:577-578.

4. Bhatla N. Abnormal \&excessive uterine bleeding. Jeffcott's principle of gynecology. Arnold, International edition 2001, pp. 32,109,486,579.

5. Drife J, McGowan B. Uterine cancer. Clinical Obstetrics \& Gynecology. Saunders, 1st edition 2004; 27:265270.

6. Anon. Endometrial bleeding. Hum Reprod update 2007;13:421-431.

7. Astrup K, Olivarus Nde F. Frequency of spontaneously occurring postmenopausal bleeding in the general population. Acta Obstet Gynecol Scand 2004;83:203.

8. Gredmark T, Kvint $S$, Havel G, Mattsson LA. Histopathological findings in women with postmenopausal bleeding. Br J Obstet Gynecol 995;102:133-136.

9. Munot S, Lane G. Modern mangment of postmenopausal bleeding. Trends in Urology Gynaecology \& Sexual Health September/October 2008.

10. Newell S, Overton C. PMB should be referred urgently.The practioner 2012;1749:13-15.

11. Wong S. Could it be cancer? investigating postmenopausal bleeding. Women's Health Journal, Primary Care 2012;4;3.

12. Tabor A, Watt HC, Wald NJ. Endometrial thickness as a test for endometrial cancer in women with postmenopausal vaginal bleeding. Obstet Gynecol 2002;99:663-670.

13. Goldstein RS. The role of transvaginal ultrasound or endometrial biopsy in the evaluation of the postmenopausal endometrium. Am J Obstet Gynecol 2009;201:5-11.

14. Munro MG. Investigation of women with postmenopausal uterine bleeding: clinical practice recommendations. The permanente journal /Winter 2014;18:55-70.

15. Sahdev A. Imaging the endometrium in postmenopausal bleeding. BMJ 2007;334(7594):635-636.

16. Smithnew-Bindman R, Weiss E, Feldstein V. How thick is too thick? When endometrial thickness should prompt biopsy in postmenopausal women without vaginal bleeding. Ultrasound Obst. Gynecol 2004 Oct; 24(5):558-565.

17. Grainger $\mathrm{R}$ G, Allison $\mathrm{D} J$. Gynecological imaging. Grainger and Allison's Diagnostic radiology. Churchill Livingstone, 5th edition 2008;54:1096-1264.

18. Goldstein RB, Bree RL, Benson CB, et al. Evaluation of the woman with postmenopausal bleeding: Society of Radiologists in Ultarsound-Sponsored Consensus Conference statement. J Ultasound Med 2001;20(10):10251036.

19. APGO educational series on women's health issues. Clinical management of abnormal uterine bleeding. Association of professors of gynecology and obstetrics, annual report May 2002.

20. Jiménez -Ayala M, Jiménez-Ayala B. Cytology of the normal endometriumcycling and postmenopausal. Endometrial adenocarcinoma, prevention and early diagnosis. Karger 2008;6:32-39.

21. Sheikh M, Swahney S, Khurana A, AL-Yatama M. Alteration of sonographic texture of the endometrium in postmenopasusal bleeding. A guide to further management. Acta Obstet Gynecol Scand 2000;79:1006.

22. Van Doorn LC, Dijkhuizen FP, Kruitwagen RF, et al. Accuracy of transvaginal ultrasonography in 
diabetic or obese women with postmenopausal bleeding. J Obstet Gynecol 2004;104:571.

23. Moodley M, Roberts C. Clinical pathway for the evaluation of postmenopausal with an emphasis on endometrial cancer detection. J Obstet Gynecol 2004;24:746-741.

24. Epstien E, Jamei B, Lindqvist PG. High risk of cervical pathology among women with postmenopausal bleeding and endometrium <or $=4.4 \mathrm{~mm}$ : longterm follow up results. Acta Obstet Gynecol Scand 2006;85:1368-1374.

25. Sasieni P, Adams J, Cuzick J. Benefit of cervical screening at different ages: evidence from the UK audit of screening histories. $\mathrm{Br} \mathrm{J}$ Cancer 2003;89:88-93.

26. Moohamed W, Thanoon M, Al-Jawadi SI. Histopathological interpretation of AUB after age of 40 Year. The Iraqi postgraduate medical Journal 2010;9:3.

27. Gredmark T, Kvint S, Havel G, Mattsson LA. Histopathological findings in women with postmenopausal bleeding. Br J Obstet Gynecol 1995;102:133-136.

28. Clinical Practice Recommendations. The permanente journal /Winter 2014;18:55-70.

29. Naik V, Rege J, Jashnani KD. Pathology of genital tract in postmenopausal bleeding. BHJ Magazine

30. Parkin D. Cancer attributable to reproductive factors in UK in $2010 . \mathrm{Br}$ J Cancer 2011;105:(S2)S73-S76.

31. Parazzini F, Vecchia CL, Negri E, Fedel L, Balotta F. Reproductive factors and risk of endometrial cancer. Am J obstet gynaecol 1991;164:52227

32. Izetbegovic S, Stojkanovic G, Ribic N, Mehmedbasic E. Features of postmenopausal Uterine Haemorrage. Medical Archives 2013;67(6):431.

33. Musonda $\mathrm{P}$, Burbos N, Duncan TJ, Crocker SG, Morris EP, Nieto JJ. Comparing the performance of two clinical models in estimating the risk of endometrial cancer in symptomatic postmenopausal women. European Journal of Obstetric \&Gynecology\&Reproductive Biology 2011;159(2):433-438.

34. Schmeler KM, Lynch HT, Chen LM, Munsell MF, Soliman PT, Clark MB, et al. Prophylactic surgery to reduce the risk of gynecologic cancers in the Lynch syndrome. N Engl J Med 2006;354:261-9.

35. Berek JS, Rinehart RD, Hillard PJA, et al. Novak's Gyneacology. 13 th edition.Lippincott Williams\&Wilkins 2002:1144-1148.

36. Saltzman BS, Doherty JA, Hill DA, et al. Diabetes and endometrial cancer:An evaluation of the modifying effects of other known risk factors. American Journal of Epidemiology 2008;167(5):607-614.

37. Jillani K, Khero R, Maqsood S, et al. Prevalence of malignant disorder in 50 cases of PMB. J Pack Med Assoc 2010;60:540-543.

38. Escoffery CT, Blake GO, Sargeant LA. Histopathological findings in women with postmenopausal bleeding in Jamaica. West Indian Med J 2002;51(2):232-5.

39. Kothapally K, Uma Bhshyakarla. Postmenopausal

bleeding:Clinicopathological study in a teaching hospital of Andhra Pradesh. International journal of reproduction, Contraception, Obestetrics and Gynaecology 2013;2:344.

40. Ninci D, Mandi A, Ziki D, Stojiljkovi B, Mastilovi K, Ivikovi-Kapicl T. Neglected case of uterine leiomyoma. 
Case report Med Pregl 2008;61(910):525-8.

41. Cheng W-F, Lin H-H, Torng P-L, Huang S-C. Comparison of endometrial changes among symptomatic tamoxifen treated and non- treated pre-menopausal and post- menopausal breast cancer patients. Gynecol Oncol 1997;66:233-7.

42. Ronghe R, Gaudoin M. Women with recurrent postmenopausal bleeding should be re-investigated but are not more likely to have endometrial cancer. Menopause Int 2010;16(1):911.

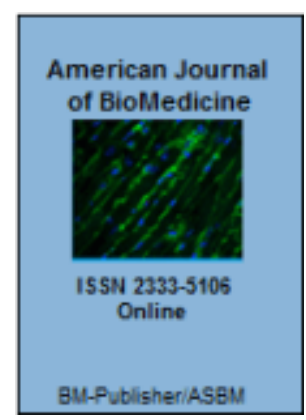

Guide for Authors

American Journal of Biomedicine listed and follow the uniform requirements for manuscripts submitted to Biomedical Journals developed by the International Committee of Medical Journal Editors (ICMJE), for more details see www.icmje.org. The uniform requirements and specific requirement of American Journal of BioMedicine are summarized below. Manuscripts should bear the full name and address, with telephone, fax, and email of the author (corresponding author). For all authors, first name and surname should be written in full. Each author should have participated sufficiently in the work to take public responsibility for the content.

American Journal of BioMedicine publishes the following article types:

- Research articles

- Database articles

- Case reports

- Software articles

- Study protocols

- Abstracts

- Review articles

- Editorial letters

Manuscript process

The manuscript submitted through our journal system and if any technique difficulty the author can submit as pdf file through editor email. After the manuscript submission by the author/s, the Editor will review the manuscripts and if the Editor determines the manuscript is appropriate for the AJBM, it will be sent to two reviewers without revealing the identification of the authors. The Editors reserve the right to choose the reviewers. Based on the comments from the reviewers, the editor will make a final decision on the manuscript. The authors will be informed about reviewer's comment. Once the manuscript has been accepted, it would be copy edited for grammar, punctuation, print style, and format. The corresponding author will receive a copy-edited article for any correction.

\section{Cover letter}

A cover letter should accompany all manuscripts submitted to AJBM indicating that the manuscript has been submitted essentially to this journal and has not previously been 
published in any form in another publication of any type, with the exception of an abstract or as part of a published lecture or academic thesis. The corresponding author should give the undertaking that if any animal/human studies carried was in accordance with their country regulatory and institutional ethical committee with proper registration of the study in the clinical registry.

\section{Research Article}

Manuscripts should be submitted in Word, use a normal, plain font (12-point Times New Roman), double spacing, margins $2.5 \mathrm{~cm}$ from all four sides, italics for emphasis, page numbers included at bottom, uniformly American English. Use the automatic page numbering function to number the pages for first submission to reviewer.

- Title page: This section should start on a new page should provide: a concise and informative title of the article; list the full names; institutional addresses; email addresses for all authors and indicate the corresponding author and a running head of not more than 80 characters.

- Abstract: This part of the manuscript should not exceed 300 words should state concisely the purpose and pertinent methods of the study, as well as the findings and specific conclusions (without title head, background, method or result)

- Keywords: Author(s) must give about 5-8 key words as index terms representing the article content which can identify the most important subjects covered by the paper. They must be placed at the end of the abstract. Do not repeat words used in the title.

- Body of Manuscript: should begin on a new page and not exceed 6000 words excluded the references and be arranged as follows:

- Introduction: Include a summary of a search of the literature to indicate why this study was necessary and what it aimed to contribute to the field and relating the manuscript to similar previous research.

- Materials and Methods: This section must contain specific details about the design of the study, materials involved, instruments used, specialized chemical source and the type of analysis used, including a power calculation if appropriate. For studies involving human participants a statement detailing ethical approval and consent should be included in the methods section.

- Results: Should be clear and concise and included statistical analysis with short informative subsections.

- Discussion: The interpreted results should be explained clearly and should relate them to the existing knowledge in the field as clearly as possible.

- Competing interests: Authors are required to complete a declaration of competing interests. All competing interests that are declared will be listed at the end of published articles. Where an author gives no competing interests, the listing will read 'The author(s) declare that they have no competing interests'.

- List of abbreviations: For standard abbreviations, authors should follow the guidelines in the Council of Biology Editors Style Manual, 5th edition. All other abbreviations should be defined when first used and listed in a footnote; Abbreviations PDF.

- Acknowledgements: List those individuals who provided help during the research and do not meet the criteria for authorship (e.g., providing language help, writing assistance or proof reading the article etc.).

- References: must be restricted to directly relevant published works, usually the total number of references should not exceed 55. AJBM follow the style adopted by the American Medical Association, which, in turn, is based on the style developed by the International Committee of Medical Journal Editors in 1978 in Vancouver. All references must be numbered consecutively and citations of references in text should be identified using Arabic numbers in square brackets before the punctuation mark. (e.g., "as study by Jonh [4]". The citations in the reference list should include 
all named authors, up to the first 3 before adding 'et al.' The reference number should follow the following format:- Reference to a journal publication: Rosenau C, Emery D, Keyboard B, Qoronfleh MW. Development of a highthroughput plate-based chemiluminescent transcription factor assay. J Biomol Screen 2004; 9: 334-42.- Article within a book:

Oyer RA, Schlossberg D. Hematologic changes in tuberculosis. In: Schlossberg D, editor. Tuberculosis \& Nontuberculous Mycobacterial infections. 5th ed. New Delhi: Tata McGraw-Hill; 2007. pp. 357-64.- Newspaper article: Tynan T. Medical improvements lower homicide rate: study sees drop in assault rate. The Washington Post. 2002 Aug 12;Sect. A:2 (col. 4).

\section{- Conference paper:}

programming. ASCO 2012: Role of IL32 in esophageal cancer

\section{- Unpublished material:}

Kim H, Philip N, Meashil E. Role of TLR4 in myocardial injury throuh NF-kB pathway. Proc Natl Acad Sci U S A. In press 2004.

\section{Preparation of graphics}

Upon submission of an article first time for reviewers, authors are supposed to include all figures and tables in the manuscript and should be submitted in separate files as:

- Figures, graphs, scatter-grams or histograms should be numbered consecutively according to the order in which they have been first cited in the text.

- Upload the images in (TIFF, GIF, JPEG, etc.) format. The file size should be within $1000 \mathrm{~kb}$ in size while uploading. Bitmap images should be of 300 dpi resolution at least unless the resolution is intentionally set to a lower level for scientific reasons more information about pixel density can be found here en.wikipedia.org/wiki/Pixel_density.

- The lettering for figures should be large enough to be legible after reduction to fit the width of a printed column.

- Titles and detailed explanations belong in the legends for illustrations in separated page after the references not on the illustrations themselves at first submitted for reviewers. After manuscript accepted, the figures and its legends must be cited in the original site.

\section{Guidelines for Human Phenotype-Genotype Association}

Refer to existing public domain websites for the Human Gene Ontology name and the number for SNPs, for more information sees: www.ncbi.nlm.nih.gov/projects/SNP

Guidelines for Proteins and Nucleic Acid Sequences

The authors must provide a statement in the manuscript that protein sequences must be deposited in GenBank or EMBL databases, and an accession number must be obtained. this sequence has been scanned against the database and all sequences with significant relatedness to the new sequence identified, for more information click this Website: www.ncbi.nlm.nih.gov/genbank

\section{Guidelines for Genomic and Proteomic Studies}

Data should follow the MIAME checklist, for more information see: www.mged.org/Workgroups/MIAME/miame.html

For the NCBI gene expression and hybridization array data repository; see www.ncbi.nlm.nih.gov/geo

\section{Accepted manuscript}

Once manuscript acceptance the editor office will ask, you to supply a Word file of the final version of your paper with all figures cited in original place. You must ensure that the file has been updated to incorporate all revisions. The article will be processed and you will receive the proofs for any further corrections in paper, authors and their addresses. The correction must be completed with 48-hours from receiving the proof otherwise the DOI number of manuscript will be activated and any further corrections will be appear in Cross 
Mark. The final published paper will be appear as abstract only for limitted access and PDF/full-text to open access article. The captions (legends) will be inserted below the figures, tables, Photographs, clinical images, photomicrographs, gel electrophoresis and cited though the paper.

Other types of Articles send as PDF or Word file direct to Editor Office editor@ajbm.net 